\begin{tabular}{|c|c|c|c|c|}
\hline Submission & Review Process & Revised & Accepted & Published \\
\hline $28-02-2020$ & $01-03$ s/d 25-03-2020 & $29-03-2020$ & $30-12-2019$ & $01-04-2020$ \\
\hline
\end{tabular}

Published by: Politik Islam UIN Raden Fatah Palembang

\title{
Pengaruh Money Politics Terhadap Pilihan Masyarakat Pada Pilkades Serentak di Kabupaten Muara Enim Tahun 2017 (Studi Kasus di Desa Teluk Limau Kecamatan Gelumbang)
}

\author{
Revi Kazali \\ Fakultas Adab dan Humaniora Universitas Islam Negeri Raden Fatah Palembang \\ Email: revi120196@gmail.com \\ Dr. Endang Rochmiatun \\ Fakultas Adab dan Humaniora Universitas Islam Negeri Raden Fatah Palembang \\ Nico Oktario Adytyas \\ Fakultas Adab dan Humaniora Universitas Islam Negeri Raden Fatah Palembang
}

\begin{abstract}
The paper is "Titled the effect of money politics on community choice in the simultaneous Pilkades in Muara Enim distric in 2017 ( Case studi in the village of Teluk Limau, Gelumbang district)". The purpose of this studi was to identify or find out how the influence of money politics on people's choices in the 2017 Pilkades and identify or find out what faktors influence people's choices in the 2017 Pilkades with the existence of money politics. The type of date used in this study is quantitative research. The location of this research is in the village of Teluk Limau, Gelumbang district, Muara Enim regency, south Sumatra province. And purely this research is the local community. To obtain date obtained numbered 1382 according to the permanent voter of samples was 93 respondents. To collecy date obtained is descriptive statiscal analyis.

Theory in this study there are two theories used, namely the theory of Patronase and Klientelisme. There are five kinds of Patronase theory namely, Vote Buying, Individual Gifs, Services and Activities, Club Goods, Pork Barrel Projects. Whereas Klientelisme theories are of three kinds, namely the successs team, the social networking engine and political parties. In this study it was elections is very big influence on people's voting behavior. In the 2017 Pilkades, the people of the village of Teluk Limau on average most of their voting behavior changes when they receive money politics. The faktors that
\end{abstract}


Revi Kazali, Endang Rochmiatun, Nico Oktario Adytyas, Pengaruh Money Politics Terhadap Pilihan Masyarakat Pada Pilkades Serentak di Kabupaten Muara Enim Tahun 2017 (Studi Kasus di Desa Teluk Limau KecamatanGelumbang), Ampera: A Research Journal on Politics and Islamic Civilization, Vol. 1 No.2, April 2020

influence the voting behavior of the Teluk Limau village in the 2017 elections are that people the and to choose the reasons because of economic faktors that have changed their choices after receiving money politics.

Keywords: Money Politics, pilkades, teluk limau village, muara enim

\begin{abstract}
ABSTRAK
Artikel ini berjudul "Pengaruh Money Politics Terhadap Pilihan Masyarakat Pada Pilkades Serentak di Kabupaten Muara Enim Tahun 2017 (Studi Kasus di Desa Teluk Limau Kecamatan Gelumbang. Tujuan dari studi ini adalah untuk mengidentifikasi atau mengetahui bagaimana pengaruh politik uang pada pilihan orang di Pilkades 2017 dan mengidentifikasi atau mencari tahu apa faktor yang mempengaruhi pilihan orang di Pilkades 2017 dengan keberadaan politik uang. Jenis penelitian yang digunakan dalam penelitian ini adalah penelitian kuantitatif. Lokasi penelitian ini adalah di Desa Teluk Limau, Kecamatan Gelumbang, Kabupaten Muara Enim, Provinsi Sumatera Selatan. Dan murni penelitian ini adalah masyarakat setempat. Penelitian ini mengambil sampel tetap sebanyak 93 responden.

Teori dalam penelitian ini ada dua teori yang digunakan, yaitu teori Patronase dan Klientelisme. Teori Klientelisme ada tiga jenis, yaitu tim sukses, mesin jejaring sosial dan partai politik. Dalam penelitian ini ternyata pemilihan sangat besar pengaruhnya terhadap perilaku memilih orang. Dalam Pilkades 2017, masyarakat desa Teluk Limau rata-rata sebagian besar perilaku pemilih berubah ketika mereka menerima politik uang. Faktorfaktor penentu yang mempengaruhi perilaku memilih di desa Teluk Limau dalam pemilihan umum 2017 adalah karena faktor ekonomi yang telah mengubah pilihan mereka setelah menerima politik uang.
\end{abstract}

Keywords: Politik uang, pilkades, desa teluk limau, muara enim

\title{
PENDAHULUAN
}

Pilkades merupakan suatu pemilihan untuk memilih pemimpin di daerah secara langsung dan demokratis. Namun, dalam penyelenggaraannya, Pilkades di kotori oleh pelanggaran-pelanggaran, salah satunya yang marak terjadi adalah praktik politik uang (money politics).Money politics merupakan salah satu bentuk pelanggaran dalam penyelenggaraan Pilkades. Money politics adalah segala bentuk pemberian uang dan barang dari kandidat kepada pemilih yang bertujuan untuk mempengaruhi pemilh. Dalam pelaksanaan Pilkades, bentuk dan pola money politics yang terjadi sangat beragam dan bervariasi.

Pemilihan kepala desa merupakan momen politik di tingkat desa yang menunjukkan bahwa masyarakat desa adalah yang sudah berpolitik secara langsung dari 
awalnya. Mengenai politik uang hal terasebut paling rawan terjadi saat menjelang pencoblosan atau sebelum satu hari pencoblosan dengan cara mendatangi kerumah masyarakat. Hal ini di Desa Teluk Limau Kec. Gelumbang Kab. Muara Enim telah terjadi praktek uang dalam pemilihan kepala desa tahun 2017 lalu yang di lakukan salah satu calon ataupun tim suksesnya untuk mendapatkan hak suaranya terhadap pemilih tersebut dengan berbagai macam cara yang mereka lakukan untuk mencuri perhatian masyarakat untuk dapat memilih calon kepala desa yang di ingingkan tersebut.

Proses pemilihan kepala desa di Desa Teluk Limau Kecamatan Gelumbang Kabupaten Muara Enim ini sama hal umumnya pemilihan kepala desa atau Pemilu yang lainnya namun akan tetapi pada Pilkades di desa ini menjelang pencoblosan seperti H-3, H-2 dan H-1 telah terjadi money politics seperti pemberian berupa uang secara kontan yang di lakukan salah satu calon kepala desa ataupun tim suksesnya sendiri dengan cara mendatangi rumah warga satu dengan yang lainnya ataupun mendatangi perkumpulan masyarakat desa serta sekelompok para pemuda/pemudi seperti karang taruna. Maka dari itu, ini merupakan money politics yang terjadi ketika ada pemilu ataupun pilkades di desa Teluk Limau Kecamatan Gelumbang Kabupaten Muara Enim ini.

Kejadian yang paling umum dalam praktek politik uang adalah pemberian suara menjelang hari pemilihan hari pemilihan. Artinya, masing-masing calon mengadakan pendekatan kepada masyarakat. Pendekatan dilakukan baik secara langsung maupun dengan melalui perantara. Pada saat inilah transaksi dilakukan baik dengan pemberian uang kontan ataupun dengan suatu janji atau pemberian cheque.

Maka dari itu fokus dalam penelitian ini yaitu bagaimana pengaruhnya money politics yang terjadi di masyarakat tersebut apakah pilihannya berubah atau tidak. Sehingga dalam penelitian ini sangat menarik di teliti karena proses pemilihan kepala desa tersebut sangat berpengaruh terhadap pilihan masyarakat yang di sebabkan adanya money politics yang di lakukan salah satu calon atau tim suksesnya sendiri. Menariknya dalam penelitian ini ialah persaingan pilkades di desa ini merupakan persaingan pilkades yang lama pada tahun Pilkades 2012, sehingga pada tahun Pilkades 2017 yang lalu kembali bertarung dan juga saling mengalahkan satu sama lain. Sehingga dalam Pilkades di Desa Teluk Limau Kecamatan Gelumbang Kabupaten Muara Enim ini menjadi perbincangan masyarakat dan sangat menarik perhatian masyarakat sekitar. Maka dari itu dalam pilkades ini peneliti sangat tertarik untuk meneliti permasalahan dalam pilkades ini.

Mengenai masalah money politics yaitu suatu upaya mempengaruhi orang lain dengan menggunakan imbalan materi atau dapat juga diartikan jual beli suara pada proses politik dan kekuasaan dan tindakan membagi-bagikan uang milik pribadi atau partai untuk untuk mempengaruhi suara pemilih. Untuk hal itu larangan mengenai praktik money politics memang sudah ada, namun di sisi penegakan hukumnya masih lemah sehingga praktik money politics yang di lakukan calon dan tim suksesnya ini terus berlangsung. Hal ini sejalan dengan perubahan perilaku memilih menjadi cenderung transaksional (jual beli suara).

Money politics adalah salah satu tindakan penyuapan berupa uang atau orang yang ditukar dengan posisi jabatan yang bertujuan untuk memperoleh suara dari par pemilih yaitu masyarakat yang mengikuti pemilu, agar dapat terpilih dan menduduki posisi jabatan yang diinginkan. Money politic dapat dilakukan oleh individu atau kelompok baik partai atau independen dengan memiliki berbagai maksud dan tujuan, dilakukan dengan 
Revi Kazali, Endang Rochmiatun, Nico Oktario Adytyas, Pengaruh Money Politics Terhadap Pilihan Masyarakat Pada Pilkades Serentak di Kabupaten Muara Enim Tahun 2017 (Studi Kasus di Desa Teluk Limau KecamatanGelumbang), Ampera: A Research Journal on Politics and Islamic Civilization, Vol. 1 No.2, April 2020

sadar dan terencana dengan baik.

\section{TINJAUAN LITERATUR}

Berkaitan dengan penelitian diatas tentang money politics ada beberapa kajian literatur yang saya jadikan rujukan dalam peneltian diatas diantaranya adalah:

Dari penelitian Fitriyah, Cara Kerja Politik Uang (Studi Kasus Pilkada dan Pilkades di Kabupaten Pati), Menjelaskan bagiamana kerja praktik politik uang dalam pilkada secara langsung menunjukan kecenderungan makin menguat sebagimana dilaporkan oleh sejumlah lembaga survey. Topo santoso memberi penjelasan mengenai apa-apa saja yang masuk kategori politik uang, menurutnya biasanya money politic dikaitkan dengan masalah suap-menyuap dengan sasaran memenangkan salah satu kandidat dalam pemilihan. Padahal sebenarnya jika dilihat secara lebih luas money politic dapat juga dihubungkan dengan segala macam pelanggarn menyangkut dana didalam konteks politik (termasuk maslah kerpartaian dan pemilu) . (Fitriah, 2012)

Selanjutnya dari penelitian H. Rahmatiah HL. , dari jurnalnya yang berjudul “ Money Politics Pada Pemilu Legislatif Tahun 2014 Di Kabupaten Gowa" mengatakan bahwa faktor penyebab masyarakat menerima money politics di sebabkan karena faktor ekonomi dan merubah pikiran dalam memilih akan tetapi masyarakat kabupaten Gowa ini di kategorikan cerdas dalam menentukan pilihan masih logis dan menggunakan nalar akibat dari berkembangnya media dan informasi yang ada. Dapat disimpulkan bahwa pemilihan umum merupakan satu pilar demokrasi sebagai wahana perwujudan kedaulatan rakyat yang menghasilkan pemerintahan menjadi yang demokratis.

Kemudian dari penelitian Dendy Lukmajati, dari jurnalnya yang berjudul "Praktek Politik Uang Dalam Pemilu Legislatif 2014 (Studi Kasus Kabupaten Blora) mengatakan dalam penelitiannya bahwa terdapat indikasi pola perilaku caleg yang di klasifikasikan kearah atau bentuk politik uang. Selain itu juga ada transaksi pemberian barang atau uang secara langsung sehingga masyarakat sudah marak sekali dengan adanya praktik politik uang dalam pilkada ini. Hal ini terjadi karena minimnya partisipasi masyarakat dalam pencegahan praktik politik uang di kabupaten Blora di pengaruhi oleh tingkat ekomomi masyarakat yang masih rendah dan pengetahuan masyarakat mengenai politik uang masih minim.

Dari penelitian Anaz Azwar, dari jurnalnya yang berjudul "Kiai, Money Politics dan Pragmatisme Politik dalam Perspektif Siyasah Syar'iyyah: Studi Kasus Pilkades Plosorejo Tahun 2013" dalam penelitiannya mengatakan bahwa seorang kiai bernama SY mencalonkan dalam pilkades dan melakukan praktik uang dalam hal memenangkan pilkades ini. Dalam menjalankan aksinya SY tidak terjun kelapangan melainkan tim suksesnya yang beraksi. Selain itu juga dalam pilkades di desa Plosorejo ini sudah terjadi sejak dulu, dan praktik politik uang ini sudah menjadi budaya tersendiri. Dalam menjalankan aksinya SY tidak terjun kelapangan melainkan tim suksesnya yang beraksi. Maka dari itu perlu adanya pengawasan yang ketat dan penegak hukum yang berwenang terhadap money politics yang terjadi. (anwar, 2016) 
Revi Kazali, Endang Rochmiatun, Nico Oktario Adytyas, Pengaruh Money Politics Terhadap Pilihan Masyarakat Pada Pilkades Serentak di Kabupaten Muara Enim Tahun 2017 (Studi Kasus di Desa Teluk Limau KecamatanGelumbang), Ampera: A Research Journal on Politics and Islamic Civilization, Vol. 1 No.2, April 2020

Sedangkan dari penelitian Zuly Qodir, dari jurnalnya yang berjudul "Politik Uang Dalam Pemilu-Pemilukada 2014: Modus dan Resolusinya" mengatakan bahwa dalam modus praktik politik uang yaitu Caleg membuat strategi bersama tim suksesnya untuk dapat mempengaruhi masyarakat seperti mengadakan bersosialisasi dengan memberikan berupa barang, hadiah dan doprize, pakaian dan bahan makanan pokok seperti minyak goreng, gula pasir, mie instan dan lain-lain. Dengan melakukan cara modus ini Caleg beserta tim suksesnya menargetkan hak suaranya yang lebih terhadap masyarakat.

Dari penelitian Fuji Hastuti dkk, Politik uang dalam PelKades Desa Cangkring dan Desa Dawuahan Kecamatan Talang Kabupaten Tegal 2012, politik uang yang terjadi sangat tinggi.Hal ini terjadi karena politik uang telah menjadi budaya masyarakat Desa Cangkring dan Desa Dawuhan. Budaya politik uang tidak lepas dari faktor kemiskinan, mentalitas, dan kultur yang melihat politik sebagai sarana untuk hal-hal yang sifatnya materialistik. Adanya slogan "laka duit laka acara nyoblos" yang dapat di artikan "tidak ada uang, berarti tidak mencoblos". Hal ini menunjukan bahwa peran politik uang di Pemilukades berpengaruh terhadap partisipasi pemilih dalam Pemilukades Desa Cangkring dan Desa Dawuhan.Bentuk maupun pola politik uang yang terjadi dalam Pemilukades Desa Cangkring dan Desa Dawuhan sangat bervariasi dan beragam. (Hastuti, 2012)

\section{METODE PENELITIAN}

Jenis penelitian dalam penelitian ini adalah penelitian kuantitatif. Metode yang digunakan dalam penelitian ini adalah metode kuantitatif, yaitu pendekatan yang terkait dengan teknik-teknik survei sosial, seperti, wawancara, kuesioner, analisis statistik, dan lain sebagainya. Data kuantitatif adalah data yang berbentuk angka atau data kuantitatif yang diangkakan. Metode kuantitatif disebut sebagai metode discovery, karena dengan metode ini dapat ditemukan dan dikembangkan berbagai iptek baru. Metode ini juga disebut metode kuantitatif kerena data penelitian berupa angka-angka dan analisis menggunakan statistik.

Penelitian ini menggunakan data primer dan sekunder. Data primer adalah data yang diperoleh secara langsung dari pihak yang menjadi sumber penelitian di lapangan.Data sekunder adalah data yang diperoleh dari mengutip berbagai sumber tertulis yang erat kaitannya dengan penelitian ini seperti buku, literatur, dan referensi lainnya.

Populasi dan sampel dalam penelitian ini diambil adalah seluruh masyarakat desa teluk limau dan berdasarkan jumlah penduduk Desa Teluk Limau yang terdaftar di data pemilihan kepala desa teluk limau. Yaitu populasinya berjumlah 1.328 dan sampelnya yang telah dibagi menggunakan rumus slovin berjumlah 93 responden. Untuk mengolah datanya mengguna random sampling.

\section{HASIL DAN PEMBAHASAN}

Studi ini hendak melihat bagaimana pengaruh money politics terhadap pilihan masyarakat dalam mengarahkan perilaku memilih pada Pilkades di desa Teluk Limau 
Kec. Gelumbang Kab. Muara Enim pada tahun 2017. Selain itu, di butuhkan teori-teori yang relevan yang akan di teliti, adapun penelitian ini menggunakan dua teori yaitu, teori Patronase dan Klientelisme. Dengan menggunakan pendekatan patronase, penelitian ini akan melihat bagaimana berbagai bentuk relasi yang kerap terjadi di ranah politik lokal pada bentuk politik patronase dan klientilisme. Sebagaimana yang didefinisikan oleh Aspinall dan Sukmajati dalam menjelaskan bagaimana pemilu legislatif dan pilpres pada 2014, mereka melihat bahwa ada hubungan timbal-balik antara patronase dan kecurangan pemilu. Patronase merujuk pada materi atau keuntungan lain yang didistribusikan oleh politisi kepada pemilih atau pendukung.

Dalam konteks politik lokal terutama untuk kepentingan pemilihan, patronase merupakan pemberian uang tunai, barang, jasa, dan keuntungan ekonomi lainnya yang didistribusikan oleh politisi berupa bantuan yang ditujukan untuk individu dan kepada kelompok/komunitas. Dapat juga berupa uang tunai atau barang yang didistribusikan kepada pemilih yang berasal dari dana pribadi atau dana-dana publik milik pemerintah yang pendistribusiannya dilakukan dengan tujuan mendapat dukungan untuk pejabat pemberi bantuan. Bentuk-bentuk patronase mncakup lima bentuk yaitu, pembelian suara (vote buying), pemberian-pemberian pribadi (individual gifts), pelayanan dan aktivitas (services and activities), barang-barang kelompok (club goods), dan proyek-proyek gentong babi (pork barrel projects).

Sedangkan klientelisme menggambarkan hubungan klientelistik dalam bentuk jaringan makelar suara yang umum digunakan di Indonesia, di mana bentuk jaringan broker dirumuskan berdasarkan hasil penelitian yang berkaitan dengan politik uang. Bentuk jaringan broker suara dalam kasus ini termasuk tiga bentuk jaringan yakni tim sukses, mesin jejaring sosial, dan partai politik.

Tim sukses, adalah jaringan makelar politik yang umum digunakan, dan biasanya dibungkus dengan istilah tim pemenangan. Mesin-mesin jaringan sosial dalam tinjauan yang disediakan oleh Aspinall dan Sukmajati lebih seperti pemimpin komunitas yang berpengaruh, Pemanfaatan tokoh masyarakat sebagai mesin jejaring sosial dilakukan oleh kandidat dengan harapan bahwa pengikut tokoh-tokoh ini dapat didorong untuk mendukungnya. Partai politik adalah jaringan pialang yang memainkan peran terkecil dalam mengorganisir kampanye di akar rumput untuk mendukung kandidat.

Pemilihan Kepala Desa yang diadakan di desa Teluk Limau merupakan termasuk salah satu Pemilihan Kepala Desa serentak di Kabupaten Muara Enim yang dilaksanakan pada hari Kamis, Tanggal 28 September 2017 sebanyak 37 Desa di 13 Kecamatan yang tersebar di Kabupaten Muara dan termasuk juga Desa Teluk Limau Kecamatan Gelumbang. Pemilihan Kepala Desa di Desa Teluk Limau ini ada 4 orang mencalonkan diri sebagai kepala desa, yang mana masing-masing merupakan putra daerah desa tersebut. Nomor Urut 1.Tri Sutrisno, Nomor Urut 2. Ahmad Redi, Nomor Urut 3 Didi Sarkini, dan Nomor Urut 4. Muhammad Amin.

Ada beberapa faktor yang terjadi dalam Pilkades tahun 2017 yang diselenggarakan di Desa Teluk Limau ini terkait adanya permainan money politics yang dilakukan beberapa calon kades maupun tim suksesnya, sehingga dalam hal ini dapat mempengaruhi dalam perilaku memilih masyarakat. Perilaku memilih merupakan tingkah laku seseorang dalam menentukan pilihannya yang dirasa disukai atau paling cocok dengan dirinya. Dimana dalam teori perilaku pemilih ada 3 pedekatan yang bisa di gunakan untuk 
Revi Kazali, Endang Rochmiatun, Nico Oktario Adytyas, Pengaruh Money Politics Terhadap Pilihan Masyarakat Pada Pilkades Serentak di Kabupaten Muara Enim Tahun 2017 (Studi Kasus di Desa Teluk Limau KecamatanGelumbang), Ampera: A Research Journal on Politics and Islamic Civilization, Vol. 1 No.2, April 2020

menganalisis perilaku pemilih yaitu dilihat dari pendekatan sosiologis, pendekatn psikologis dan pendekatan Rational Choice (Pilihan Rasional).

Setelah dilakukannya penelitian dilapangan dengan cara menyebarkan kuisioner atau angket yang dilakukan oleh peneliti maupun dengan cara membacakan angket kepada responden, maka telah didapatkan berbagai data mengenai keadaan responden serta jawaban-jawaban dari beberapa pertanyaan yang diajukan dalam kuisioner atau angket tersebut. Sampel yang diambil oleh peneliti sebanyak 93 responden. Dimana peneliti dalam menentukan responden dengan menggunakan random sampling artinya peneliti mengambil responden secara acak, tidak melihat strata pada sampel. Penelitian ini membahas data-data yang diperoleh selama menjalankan penelitian dari tanggal 20 Juli sampai dengan 30 Agustus 2019 di Desa Teluk Limau Kecamatan Gelumbang Kabupaten Muara Enim Provinsi Sumatera Selatan.

Pada hasil penelitian yang ada berjumlah 93 responden dan dari beberapa pertanyaan dari peneliti $100 \%$ menjawab semua dari seluruh responden penduduk Desa Teluk Limau, yang dimana masyarakat cenderung memilih Calon Kades dengan nomor urut 4 yaitu Bapak Muhammad Amin dengan 49 orang yang memilih dari 93 responden. Pada dasarnya memang pada Pilkades 2017 Desa Teluk Limau ini dimenangkan oleh nomor urut 4 Bapak Muhammad Amin dengan memperoleh 409 suara. Namun Pilkades 2017 ini tercoreng dengan adanya bermain Money Politics yang dilakukan beberapa calon untuk jual beli hak suaranya.Pengaruhnya Money Politics didesa Teluk Limau ini sangatlah besar, terbukti dari jawaban responden yang menerima Money Politics berjumlah 84\% dari jawaban responden. Artinya memang pada Pilkades 2017 ini bermain Money Politics untuk mendapatkan hak suaranya dengan cara membeli suara masyarakat dengan uang tunai sebesar 100.000 dan uang tunai 50.000. Sehingga Money Politics pada Pilkades 2017 ini sangat berpengaruh terhadap perilaku memilih.

Perilaku memilih masyarakat Desa Teluk Limau dalam menentukan pilihan Calon Kadesnya berdasarkan pendekatan teori perilaku memilih mempunyai tiga pendekat, yaitu pendekatan sosiologis, pendekatan psikologis, dan pendekatan rational choice (pilihan rasional). Pendekatan sosiologis adalah pendekatan dimana responden melihat berdasarkan jenis kelamin, usia, pendidikan, pekerjaan, agama, suku dan penghasil tingkat ekonomi. Pendekatan psikologis adalah pendekatan yang digunakan peneliti untuk membaca perilaku memilih masyarakat desa Teluk Limau dalam menentukan pilihannya. Sedangkan pendekatan pilihan rasional adalah pendekatan yang digunakan untuk membaca perilaku memilih masyarakat berdasarkan tingkat keuntumgan yang diperoleh oleh pemilih.

Berdasarkan kecenderungan kesamaan jawaban responden atau pendapat mayoritas responden yang telah mengisi kuisioner. Dari 93 responden hanya 37 orang responden yang mengetahui isi kampanye setiap calon kades pada Pilkades 2017. Artinya memang masyarakat Desa Teluk Limau tingkat pengetahuan visi/misi dari setiap kandidat calon kades sangatlah minim sekali. Sehingga dapat mempengaruhi perilaku memilih masyarakat Desa Teluk Limau dalam menentukan pilihannya.

Pada pendekatan perilaku memilih, masyarakat cenderung memilih calob kades berdasarkan saran dari Tim Sukses, dengan cara mengajak maupun mendatangi mereka kerumah masing-masing. Terlihat dari jawaban responden dari 93 responden dan sejumlah 79 orang yang didatangi atau diajak Tim Sukses untuk memilih yang disarakan 
Revi Kazali, Endang Rochmiatun, Nico Oktario Adytyas, Pengaruh Money Politics Terhadap Pilihan Masyarakat Pada Pilkades Serentak di Kabupaten Muara Enim Tahun 2017 (Studi Kasus di Desa Teluk Limau KecamatanGelumbang), Ampera: A Research Journal on Politics and Islamic Civilization, Vol. 1 No.2, April 2020

oleh Tim Sukses. Perilaku memilih masyarakat desa Teluk Limau tidak melihat kesamaan pendekatan psikologis seperti jenis kelamin, usia, agama maupun suku. Mealainkan cenderung memilih untuk mendapatkan keuntungan sendiri dengan mendapatan uang untuk memberikan hak suaranya.

\section{KESIMPULAN}

Pada hasil penelitian dan analisis data terhadap penelitian "Pengaruhnya Money Politics Terhadap Pilihan Masyarakat Pada Pilkades Serentak Di Kabupaten Muara Enim tahun 2017 (Studi Kasus Di Desa Teluk Limau Kecamatan Gelumbang)”. Dapat disimpulkan bahwa dari data yang dianalisis pengaruhnya money politics terhadap pilihan masyarakat Desa Teluk Limau sangatlah besar pengaruhnya.

Terlihat dari hasil data yang ditemukan dari seleruh jawaban responden masyarakat Desa Teluk Limau yang diambil terdapat $73 \%$ responden yang menerima money politics. Sehingga berpengaruh perilaku memilih masyarakat. Terlihat jelas bahwa dari $73 \%$ yang menerima money politics ini terdapat dua calon kades yang bermain money politics yaitu calon Nomor Urut 1 Bapak Tri Sutrisno dan Nomor Urut 4 Bapak Muhammad Amin. Dan dimana pada data yang didapatkan bahwa selisih responden dua calon kades ini tidak jauh berbeda, yaitu dari seluruh jawaban responden yang memilih Nomor Urut 1 Bapak Tri Sutrisno 35,5\% dan yang memilih Nomor Urut 4 Bapak Muhammad Amin 52,7\% . Pada dasarnya juga Pilkades 2017 ini dimenangkan oleh Bapak Muhammad Amin dengan mendapatkan 409 suara.

Artinya pengaruh money politics pada Pilkades 2017 di Desa Teluk Limau ini sangat besa terhadap pilihan masyarakat ketika menerima uang yang diberikan oleh calon kades tersebut maupun tim suksesnya, terlihat pada jawaban responden yang didapat bahwa yang berubah pilihannya ketika menerima money politicssebanyak $67 \%$ dari seluruh data responden yang didapat. Dengan alasan berubah pilihan cenderung karena mendapatkan keuntungan pribadi.

Faktor yang mempengaruhi perilaku memilih terhadap money politics pada Pilkades tahun 2017 di Desa Teluk Limau Kecamatan Gelumbang Kabupaten Muara Enim ini cenderung masyarakat memilih karena faktor ekonomi. Terlihat pada data yang didapatkan dari hasil penelitian bahwa faktor ekonomilah yang merubah perilaku memilih masyarakat. Sedikit yang alasan karena faktor keluarga maupun sosial terhadap perilaku memilih masyarakat Desa Teluk Limau. 
Revi Kazali, Endang Rochmiatun, Nico Oktario Adytyas, Pengaruh Money Politics Terhadap Pilihan Masyarakat Pada Pilkades Serentak di Kabupaten Muara Enim Tahun 2017 (Studi Kasus di Desa Teluk Limau KecamatanGelumbang), Ampera: A Research Journal on Politics and Islamic Civilization, Vol. 1 No.2, April 2020

\section{DAFTAR PUSTAKA}

Akbar, Andi. (2016). "Pengaruh Money politic terhadap Partisipasi Masyarakat pada Pilkada 2015 di Kabupaten Bulukumba (Studi kasus Desa Barugaf Kec. Bulukumpa)'.Skripsi, (Filsafat dan Politik. Fakultas Ushuluddin. UIN Alauddin Makassar).

Aspinall, edward dan Mada Sukmajati. (2014) Politik uang di Indonesia Partonase Dan Klientelisme Pada Pemilu Legislative 2014, Yogjakarta: PolGov

Azwar, A. (2017). Kiai, Money Politic dan Pragmatisme Politik dalam Perspektif Siyasah Syar'iyyah: Studi Kasus Pilkades Plosorejo Tahun 2013. IN RIGHT: Jurnal Agama dan Hak Azazi Manusia, 5(2).

Fitriyah, F. Cara Kerja Politik Uang (Studi Kasus Pilkada dan Pilkades di Kabupaten Pati). Politika: Jurnal Ilmu Politik, 6(2), 101-111.

Hastuti, Fuji dkk, "Politik uang dalam PemiluKades Desa Cangkring dan Desa Dawuahan Kecamatan Talang Kabupaten Tegal 2012. Universitas Diponerogo

Lukmajati, Dendy. "Praktek Politik Uang Dalam Pemilu Legislatif 2014 (Studi Kasus Kabupaten Blora)". Jurnal Politika.Vol. 07, No. 01, April 2016

Rifai, Amzulian.(2003). Politik Uang dalam Pemilihan Kepala Daerah. Cet. Ke-1, Jakarta: Ghalia Indonesia

Siregar, Syofian (2013) Metode Penelitian Kuantitatif Dilengkapi Dengan Perbandingan Perhitungan Manual \& SPSS. Jakarta: Prenadamedia Group

Sugiono. (2013).Metode penelitian Kuantitatif dan kualitatif $R d D$. Bandung: Alfabeta $\mathrm{CV}$,

Yusuf, Muri (2014). Metode Penelitian Kuantitatif, Kualitatif \& penelitian gabungan. Jakarta: Kencana 